\title{
Research on the Application of Law Talent based on the Reform of Law Education Method
}

\author{
Liping Zhang
}

Oxbridge College Kunming University of Science and Technology, Kunming, Yunnan, 650106

Keywords: Law Talents Training, Law Education Method, Application Research

\begin{abstract}
We have to talk about legal training model, first of all have to talk about talent training mode, and then extended. From the connotation and denotation of the talent cultivation mode, there are mainly the types of training patterns, the expected results to be achieved, and the process of achieving this foreseeable effect. Of course, there are also the approved measures in this process. And then extended, then the legal talent training mode, we generally talk about its meaning, its rank, and its framework, which is from the horizontal, then in terms of vertical, more in-depth it Can reach the end of the whole society to its positioning, as well as its theoretical cornerstone and so on.
\end{abstract}

\section{Introduction}

China's legal professional training after decades of practice and exploration, has now formed a basic legal personnel training model. However, the existing legal education has been unable to meet the needs of contemporary legal education for the legal profession, such as the irrationality of the allocation of resources and the layout of the legal personnel education, the unclear Law Training mode, the practice and education Theory is not able to complement communication. At the same time, how can we make these problems better to deal with it, we have to create a relatively perfect talent training model, to deal with the direction of the law students in all aspects of expectations. Therefore, it is particularly important to explore a new model of high-level applied legal personnel training in line with Chinese law. In this paper, through the elaboration of the connotation of the applied legal personnel training mode and the current situation and existing problems of the applied legal personnel training mode in China, the author draws on the relevant theories of the domestic and international personnel training mode, and draws lessons from the foreign high-level applied legal personnel training mode Practice and experience, try to make an important theoretical guidance for China to realize the construction of applied legal talent innovation base, and finally pave the way for China to cultivate high-level applied Law Talents to meet the needs of China's modernization.

\section{The Application of the Role of Law Training Model}

At present, the main force of law education in our country is concentrated in the teaching of the course, and the purpose of these courses is the form of books, there is little practice, let alone what leap-like links, which is not conducive to the export of legal personnel, Obviously, this is the requirement to constantly improve and perfect, so as to show the characteristics of the law profession, which itself is a very professional practice, in some specific practical subjects, such as moot court, clinic-style teaching methods, Practicality is relatively strong. But the role it really can play is very limited. The lack of practical courses has seriously affected the improvement of students' professional quality. The ability of legal personnel to use legal knowledge to solve practical problems can not be greatly strengthened. The application of Law Talents training mode can provide students with a broad platform, It can give full play to the students' own initiative, practical ability to collect and examine the ability to examine a variety of information, on the other hand, for other disciplines applied to cultivate personnel, to provide some guidance and even reference.

China's legal education is facing the lack of teaching funds and the proportion of dual teachers is not high two major issues. These two problems also restrict the development of practical teaching in 
China. These problems lead to the practice of education has not yet achieved the desired effect, for which we must strive for national and social support, make full use of existing resources to become the focus of our next step to improve the treatment of school teachers and hired high knowledge of talent is also resolved Double teacher type is an important way.

Application of legal personnel training model to students as the main body of activities, students can be very good to develop their own vision, ahead of familiar with the future work environment, a more realistic understanding of the connotation of legal knowledge. First of all, he made the students actively play the initiative to think about the problem, vigorously to enhance the students want to learn the root cause of power; in other words, the students to solve practical problems and the ability to innovate will be substantially improved.

\section{Objectives of the Application of Personnel Training}

Application of talent training objectives to cultivate the application of talents for the purpose, pay attention to cultivate students' knowledge and skills of the organic combination, optimize the overall quality of students. It is based on the needs of the community, based on the school's school level, service-oriented and service areas, highlighting the practicality of personnel, adaptability and development, legal application of personnel training these goals at this stage, we can from these aspects To understand:

First, reinforce the legal knowledge base. The professional knowledge of law is the basis and prerequisite for cultivating the applied law specialty. Without the basic knowledge of law, the cultivation of applied talents must be blind, and the knowledge gained through the cultivation of law practice courses must be fragmented. In fact, this has to ask our legal person to the basis of their own poor, solid foundation can only build high-rise, legal knowledge should be proficient in the heart, a comprehensive grasp of deep understanding and digestion and absorption.

Second, poor practical practice skills. Read the book as a thousand miles, the theory can not put aside more practice, practice is the only standard to test the truth, practice in the application of legal personnel should occupy a very important position. Practice and theory in the requirements of legal professionals, they should be more so that they have improved in the legal knowledge level, but also to the book of theoretical knowledge applied to real life, to serve to create a new legal application of talent, both complement each other After solving the problem and self-improvement dialectical contact with the development of the. More clearly that is to learn the knowledge of students to solve practical problems.

Third, to enhance the corresponding ability to innovate. Innovation is the soul of a nation's progress, the country is an inexhaustible power of prosperity. Innovative thinking is the ability to break through the old-fashioned model, jump out of the inherent rigid way of thinking to think things to deal with the problem. At this stage, the practice of our country has emerged a new problem, and these problems are varied. Therefore, an applied legal person must be able to analyze and solve the problems in the practice of law. This is also an important guarantee for the continuous development and continuous improvement of Law Talents.

Fourth, to enhance social adaptation skills. At present, our society is in an important turning point. Rapid changes in the various environments: interpersonal, ideological environment and open the social environment, the ability of applied talents made a high demand. Ask them to learn to adapt, learn to cooperate, and better to interact with people. Applied legal personnel should also have a certain degree of ability to cope with changes in the social environment. Otherwise, it will inevitably lead to negative consequences, such as due to changes in the social environment, thus affecting the ability to limit their legal application performance.

\section{Training the Main Teaching Methods of Applied Law Talents}

The case teaching method in the field of law education refers to the teaching method of interpreting the content of the grammar and cultivating the practical application ability of the students through the guidance of the teachers, the students' independent analysis and the study of the existing cases. 
The case refers to an actual or virtual plot event to illustrate a theoretical principle, to confirm a legal opinion or to reflect the various problems that arise in judicial practice. In teaching practice, students can analyze, discuss and stimulate their thinking through the analysis of cases, so that they rise from sensibility to rational knowledge, and in the strong interest in learning to master the relevant knowledge. Case teaching method has the following characteristics: the universality of the application. It helps teachers find the lack of theoretical teaching. It is conducive to mobilize the initiative of students learning, enthusiasm. It is an effective form of classroom teaching theory. It is the most appropriate form of theory and practice. The case teaching method is the most appropriate form of theory and practice. The case study method is the most suitable form of theory and practice, and it is difficult to understand. It not only enables students to understand and master the legal knowledge from the combination of theory and practice, but also to cultivate and train students to use the knowledge to analyze and solve problems.

Simulated court teaching method is a kind of teaching method which simulates the process of court trial in the process of law teaching. The students themselves play the judges and parties and agents in the examination, prepare their own trial materials, and analyze, summarize, construct and construct according to the case materials provided by the teachers, thus forming the facts to be made to the law. Mock court is an effective way to exercise students' practical ability. Can be used to cultivate students' legal ability to explain, legal reasoning ability, legal ability to use, the ability to use evidence, the ability to debate the court, the ability to produce legal instruments, these are the legal talent as an indispensable ability. Moot court is a systematic, whole process of training. Moot court is a vivid, lively way of teaching. It is precisely because the training provided by the moot court is more realistic, more close to practice, more systematic and comprehensive, the courtyard of the lifeless law education into a dynamic and lively mode, to make up for the traditional legal education in the lack of Kind of widely used teaching methods.

Legal clinic education, also known as "clinical law education", originated in the United States in the 1960s, the starting point is to follow the medical school using the practice of doctors in the form of training, through the guidance of law students to participate in the actual legal application process to develop students The ability to practice the law, to teach students to "like the legal profession to think about the problem," pay attention to teach students to change the basic knowledge of the future, in the future to deal with a variety of complex legal requirements of the necessary legal principles, principles , Lawyers career-specific way of thinking and find problems, to determine the problem, the ability to solve the problem, which is the life of the students is essential. It is different from the previous "Qi duck" education, its main features are: to stimulate students to solve the problem of enthusiasm, enhance their interest in learning, to cultivate their independent thinking of practical problems of thinking habits. The legal clinic teaching method allows students to understand the gap between theory and practice, and to know the unpredictable situation in the theoretical classroom. Clinic Legal education is a way of teaching the combination of legal theory and legal practice.

Clinic legal education can achieve the following benefits: ${ }^{1}$ Train students 'basic skills in legal practice and enhance students' understanding of "practicing truth". It provides students with the opportunity to contact the parties in real terms, to develop students' professional ethics and sense of responsibility. It promotes the level of student law theory and the comprehensive understanding of laws and regulations. Provide legal services to help the community. The value of this education is that in the campus at the same time the classroom teaching and the actual case together, the educator is both a student and a lawyer, the clinic is both a classroom and a law firm. Compared with other courses in law schools, clinic legal education has its special side, that is, more emphasis on the combination of theory and practice.

\section{Conclusion}

With the deepening of the reform of law teaching, more and more colleges and universities realize that legal education is not only the training of law teachers, legal researchers and other disciplines of theoretical talent, more importantly, the need to cultivate the community judges, lawyers, legal 
advisers Applied legal talent, because the latter's society needs more and more urgent. Therefore, many institutions of higher learning have laid the talents of undergraduate law education in the practical talents with solid foundation, wide knowledge, strong ability and high quality, and attach importance to the cultivation of students' practical ability. Only by using the teaching method suitable for cultivating applied Law Talents can we adapt to the training requirements of applied Law Talents. Practice has proved that case teaching method, moot court teaching method and clinic teaching method are effective teaching methods which can cultivate students' practical ability.

\section{Acknowledgements}

2013 Yunnan Department of Education Quality Engineering Construction Teaching Reform Research Project: diversified cooperation and training of applied talents collaborative education model innovation research

\section{References}

[1] Liu Gen, Chen Jianhui. The application of legal personnel quality structure [J]. Old area construction, 2012 (Z1)

[2] Wei Haiqun. Application of Applied Law Talents in Colleges and Universities [J]. Chinese Journal of Personnel, 2012 (08)

[3] Xie Zhizhao, Wang Xianghong. German universities to cultivate the application of Law Talents experience [J]. Contemporary Education Forum, 2012 (03)

[4] Liu Xiaoxiao. Application of applied legal personnel training in local colleges and the confusion and practical choice [J]. Journal of Chongqing College of Education, 2011 (01)

[5] Li Zhenkun. Discussion on the cultivation of applied Law Talents [J]. Journal of Jilin Radio \& Television University, 2010 (07)

[6] Liu Xiaoxiao. Perceptions and realistic selection of applied legal personnel training in local colleges and universities [J]. Journal of Changchun Institute of Education, 2010 (04) 